\title{
Centralization and decentralization reform in school education in Nepal: Tracing the swing of the pendulum
}

Khanal, Peshal

Canterbury Christ Church University, United Kingdom (p.khanal78@canterbury.ac.uk)

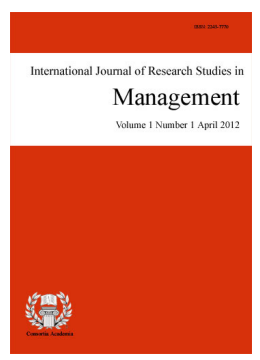

Received: 28 September 2012

Revised: 22 October 2012 DOI: $10.5861 /$ ijrsm.2013.400

Accepted: 23 January 2013

\section{Abstract}

This article revisits the school policies in Nepal focusing on the dynamics of centralization and decentralization of school management. It is argued that the policies in a large part of the country's history remained under the strong influence of national politics and domestic agendas, but after 1990, the government's commitment to the global campaign of universal primary education and its overreliance on the donor-driven agenda have combined to exert an 'external' influence on the school policy. The rise and fall of a democratic polity in different historical periods led to a swing in school policy from centralization to decentralization. This article concludes that the current school decentralization reform has been a result of confluence of three forces - historical, democratic and international. As the country now is embarking on a large-scale political reform - a federal constitution and many ethnic and political groups are lobbying for their own agendas of power sharing, the school decentralization policy is likely to be further affected by the outcomes of this macro-political process. Based on the reflection of centralization and decentralization of school management at various historical times, this article suggests for a bottom-up process in the making of public policy.

Keywords: centralization; decentralization; Panchayat; Rana; Nepal 


\section{Centralization and decentralization reform in school education in Nepal: Tracing the swing of the pendulum}

\section{Introduction}

There has been considerable discussions and debates about the choice between centralization and decentralization of education as central and local decision-making each have their own strengths and shortcomings. However, for the last few decades school reform underpinning decentralization has been a priority agenda among policymakers and planners both in developed and developing countries. The policy of centralized or decentralized governance is, indeed, largely a political option; thus, the ideology governing the political system of a country decides very much the extent to which authority and power are devolved from the centre to the local level.

Drawing upon the policy papers, study reports and other historical evidence, this article looks at how the Nepali school policies took on the issue of centralization and decentralization at various historical times and how the political upheavals in the country influenced the dynamics of power sharing between the central and subnational entities. It is argued that the school policies in a large part of the country's history remained under a strong influence of the national politics and domestic agendas, but after 1990, the global campaign of universal primary education and the country's overreliance on the donor-driven agenda has added a new 'external' dimension to the school policy. Moreover, the rise and fall of a democratic polity in the country, as well as the post-1990 influence of donor organizations led to the policy swing from centralization to decentralization.

This article is divided into two major sections. The first section provides a brief political history of Nepal with a view to setting educational reform within the broader context of socio-political changes. This section also provides a context for the subsequent analyses and discussions. The second section analyses the policies and development of school education, keeping a central focus on the debate of centralization and decentralization of school management and decision-making. Finally, some conclusions are drawn.

\section{A brief political history of Nepal}

\subsection{Unification}

Nepal's emergence as a modern state is relatively late in comparison with the history of many so-called developed nations. Until the latter half of the eighteenth century, the existing territory of the country was split into a number of small principalities - 22 to the east of the Kathmandu Valley, 24 to the west and 3 within the Valley itself (Devkota, 2036B.S. ${ }^{1}$ ). In the latter half of the eighteenth century, Prithvi Narayan Shah, a ruler of Gorkha, ${ }^{2}$ conquered several fiefdoms and principalities to unify Nepal, taking advantage of their pretty wrangling. He became the King of a unified Nepal in 1769, which marked the beginning of the modern history of Nepal.

The unification of the country in 1769 also laid the foundation of the hereditary monarchy ${ }^{3}$ as a ruling system of the country. However, because of the myopic and less heroic kings following the demise of King Prithvi, monarchical power was gradually taken over by successive Prime Ministers. The monarchy lost its executive

\footnotetext{
1 The Bikram Sambat (B.S.) is popularly used calendar in India and official calendar of Bangladesh and Nepal, which is 56 years, 8 months and 15 days ahead of the solar Gregorian calendar. Before Nepal's emergence as a nation in the latter half of the 18th century, the designation 'Nepal' was largely applied only to the Kathmandu Valley.

${ }^{2}$ Gorkha was one of the 24 Kingdoms in the west of the Kathmandu Valley.

3 Beginning from the first King Prithvi, King Gyanendra Shah was the $11^{\text {th }}$ and the last King in Shah Dynasty, whose reign was ended in 2008 following the People's Movement in April 2006.
} 
power in 1846 when Jung Bahadur Rana, an upstart and a close aide to the then Queen, plotted the infamous Kot massacre ${ }^{4}$ and assassinated all the court and political leaders of Nepal in a single swoop and proclaimed himself the Prime Minister of the country. After this event, he took all administrative and military power from the monarchy, reducing the King to a mere figurehead. The Prime Minister's position then became hereditary, and the Rana family continued their reign for over a century, with the Shah Kings virtual prisoners in the palace.

\subsection{Rana oligarchy}

The Rana period (1846 - 1950) is indelibly marked as a dark age in the history of Nepal. Notably, the access to education was denied by the Ranas with a fear that if the commoners had political freedom and the privilege of schooling, they would awaken to a revolt against their monocracy (Sharma, 1990). With cowardice and xenophobic mindset, the Ranas barred the Nepali citizens from engaging in any kind of activities that could enlighten and awaken them. Thus, under the disreputably autocratic rule of the nine Rana Prime Ministers, Nepal's educational progress remained almost at a standstill, during a period when most of the countries laid a solid foundation for development and modernity.

Despite the Ranas depriving the commoners of their political and educational rights, a significant number of people went to India for education, and some of the politically motivated students began a campaign to establish democracy in the country. A few courageous youths in Kathmandu were actively involving in imbibing and spreading anticolonial and democratic ideals. With their initiative, a new political party, named Praja Parishad, was formed which organised some sporadic anti-Rana protests in Kathmandu during the 1940s. Four active members of Praja Parishad were later put to death for their alleged conspiracy to overthrow the Rana government. The then King Tribhuvan himself was also seeking to liberate the country from the Rana's oligarchy and thus provided a clandestine support to the members of Praja Parishad.

Concurrently, the liberation of India from the British Raj served as a powerful catalyst for weakening the Rana's external support base. ${ }^{5}$ At this crucial juncture, the King fled to India in November 1950 and sought their support for uprooting the century-old autocracy from the country. Because of both domestic and external pressure, the Ranas were finally deposed, and the country entered into a new era of democracy. Therefore, the middle year of the $20^{\text {th }}$ century marked the watershed in Nepal's political history.

\subsection{Short-lived democracy}

The following decade (1951 - 1960), nonetheless, remained very unstable. King Tribhuvan died in 1955 and was succeeded by his son Mahendra and then several governments were experimented. The first general election was held later in 1959 and the leader of the Nepali Congress, B. P. Koirala, became the first elected prime minister of Nepal. Despite the long-awaited popular election and the formation of democratic government, the honeymoon between the monarchy and democracy was short-lived.

\subsection{The Panchayat System}

The King dissolved parliament within a year, placed the entire cabinet under arrest, banned the political parties, and embarked on his experiment in the Panchayat system. The system was rife with political monopoly and bad governance and not democratic in the least (Gaige, 1968; Baral, 1980). After the death of King Mahendra in 1972, his son Birendra succeeded him. The political monopoly during Birendra's reign resulted in riots in 1979, which forced the King to call for a national referendum. The referendum was to decide the fate of the Panchayat system in favor of a multiparty system. Held in May 1980, the referendum gave a narrow victory to the Panchayat system, but many believed it to be rigged (Gurung, 1982). The King carried out some promised minor reforms, but the system stayed largely the same.

\footnotetext{
4 The massacre was held at the courtyard of the palace armory (Kot) on 14 September 1846.

5 The Ranas were staunchly pro-British and assisted the British during the Indian Rebellion of 1857 and later in both World Wars.
} 


\subsection{Restoration of democracy}

In 1990, the Nepali Congress and the United Left Front, the parties outlawed by the Panchayat government, formed an alliance with the aim of bringing down the Panchayat system and reviving democracy in the country. This was the time when the government had strained relations with India in connection with a dispute of access to the port, following the expiration of trade and transit treaty in 1989 (Koirala, 1991). This helped the alliance gain support from the government and the major political parties of India to fight against the Panchayat government. In February 1990, the Nepali Congress and the United Left Front jointly announced the Jana Aandolan (People's Movement), a nonviolent prodemocracy movement. The two-month Jana Aandolan was initially dealt with severely, more than 50 people were killed by police gunfire and hundreds arrested. In April, the King finally capitulated as the movement swelled and gained a massive groundswell of support. Consequently, he dissolved the Panchayat system, lifted the ban on political parties, released all political prisoners and reintroduced multiparty democracy, relinquishing much of his own powers. Then another age of democracy began in the country.

The various governments elected after the restoration of democracy, however, could not perform as people had hoped. Continual infighting among the major parties fractured governance, resulting in numerous governments and reshuffles. Corruption dogged politicians and major reforms had been slow to come. It was in this situation that, in 1996, a minor left party (later known to be the Nepal Communist Party, Maoist) with some members in parliament took up arms and started the 'People's War'.

\subsection{The Maoist insurgency, demise of monarchy and the declaration of federal country}

The period between 1996 and 2005 has been depicted as a tragic decade in the history of Nepal as the Maoist-inspired insurgency cost nearly 13,000 lives and shattered peace, stability and development in the popularly-known Himalayan kingdom. ${ }^{6}$ Two important political developments nonetheless brought the Maoists and the seven major political parties to the negotiating table in December 2005. First, the Maoist assessed that winning the 'People's War' militarily was almost unattainable unless they ventured into parallel politics of bargaining and negotiation with the political parties, the government and the King. Second, after the royal massacre in 2001, King Gyanendra took over power, dissolved parliament, arrested the party leaders and virtually banned all the parties.

The concurrence of these two events led the Maoist and the seven major parties to forge an alliance to fight against the King-led government in general and the monarchy in particular. Under this historic alliance, millions of people took to the streets, and unrelenting protest for 19 consecutive days in April 2006 forced the King to give power back to the people. Following the April uprising, the monarchy remained virtually dead until the general election of the Constituent Assembly (CA) in 2008. The first meeting of the CA, held on May 282008 , finally declared the country as a 'Federal Democratic Republic of Nepal', overthrowing the century-old monarchy and writing a new history of bloodless transformation of the country from the constitutional monarchy to a republic (see table 1).

\section{Centralization and decentralization reform in education}

The history of Nepal, as just discussed, passed through various political turbulences and accordingly, educational policies in the past remained very much under the influence of the particular ideology governing political system of the country. The historical trajectory of Nepal shows that the more the government took a unitary and autocratic approach to governance, the more stringently it held the authority at the central level. In contrast, a democratic approach to governance gave rise to the widening role of the sub-national governments and community-led organizations in decision-making, as well as increased the government's reliance on

${ }^{6}$ For a detailed analysis of the Maoist's movement see Michael Hutt, Ed., Himalayan 'People's War': Nepal's Maoist rebellion (London: Hursh, 2004). 
Centralization and decentralization reform in school education in Nepal: Tracing the swing of the pendulum international policy assistance. Taking 1846 as a point of departure when the Rana rulers took over the political power, the country's politics appeared to run through both of these approaches, leading to the policy swing from centralization to decentralization (see table 2).

Table 1

Periods of recent Nepalese history

\begin{tabular}{|c|c|c|}
\hline Period & Polity & Ideology \\
\hline $\begin{array}{l}\text { Pre-unification } \\
\text { (before } 1769\end{array}$ & Petty Kingdoms & $\begin{array}{l}\text { Small warring states, Hindu Kingship, all eventually } \\
\text { conquered and unified into the present state by Prithvi } \\
\text { Narayan Shah }\end{array}$ \\
\hline $\begin{array}{l}\text { Shah/Rana }(1769-1951) \\
\text { Rana Period } \\
(1846-1951)\end{array}$ & $\begin{array}{l}\text { Patrimonial, } \\
\text { strong hereditary } \\
\text { prime ministers } \\
\end{array}$ & $\begin{array}{l}\text { Authoritarian and autocratic, strongly Hindu, supporters of } \\
\text { British Raj while minimizing foreign influences, Kings as } \\
\text { powerless figureheads }\end{array}$ \\
\hline Transition (1951-1960) & $\begin{array}{l}\text { Political freedom } \\
\text { and democracy }\end{array}$ & $\begin{array}{l}\text { Developmentalist, people-oriented, first general election and } \\
\text { party-led government but short-lived }\end{array}$ \\
\hline Panchayat (1960-1990) & $\begin{array}{l}\text { Guided, partyless } \\
\text { democracy }\end{array}$ & $\begin{array}{l}\text { Developmentalist, nation-building (i.e. ethnic languages and } \\
\text { cultures discouraged except as folklore), authoritarian, } \\
\text { political parties and religious proselytizing banned }\end{array}$ \\
\hline Multiparty (1990-2002) & $\begin{array}{l}\text { Constitutional } \\
\text { monarchy }\end{array}$ & $\begin{array}{l}\text { Developmentalist, liberal, hesitant moves towards } \\
\text { multiculturalism; constitution still bans proselytizing and } \\
\text { defines Nepal as a Hindu Kingdom, but religiously free in } \\
\text { practice }\end{array}$ \\
\hline $\begin{array}{l}\text { 'Regression' } \\
(4 / 10 / 2002-A p r i l ~ 2006)\end{array}$ & $\begin{array}{l}\text { Short-lived } \\
\text { governments }\end{array}$ & $\begin{array}{l}\text { King Gyanendra attempts to revive Panchayat-style } \\
\text { King-led polity, leading to collapse of } 1990 \text { Constitution }\end{array}$ \\
\hline $\begin{array}{l}\text { Reconstruction } \\
\text { (April } 2006 \text { onwards) }\end{array}$ & $\begin{array}{l}\text { Contested, } \\
\text { constitution } \\
\text { drafting }\end{array}$ & $\begin{array}{l}\text { Power-sharing between the seven-party alliance (SPA) and } \\
\text { the Maoists, republic state, assertive multiculturalism, } \\
\text { secular state, federal constitution drafting }\end{array}$ \\
\hline
\end{tabular}

Source. Gellner (2007)

Table 2

Historical periods of formal schooling in Nepal

\begin{tabular}{|c|c|c|}
\hline Period & Educational development & Mode of school management \\
\hline $\begin{array}{l}1846-1951 \\
\text { (Period of opposition to } \\
\text { education) }\end{array}$ & $\begin{array}{l}\text { Negligible expansion in education, access to } \\
\text { education only available to the Rana rulers and a } \\
\text { few high-caste elites }\end{array}$ & $\begin{array}{l}\text { Extreme centralization } \\
\text { under the direct control of } \\
\text { the Rana rulers }\end{array}$ \\
\hline $\begin{array}{l}1951-1971 \\
\text { (Period of quantitative } \\
\text { growth of education) }\end{array}$ & $\begin{array}{l}\text { Unplanned expansion of schools, greater } \\
\text { community engagement, and limited government } \\
\text { involvement and control }\end{array}$ & $\begin{array}{l}\text { High degree of } \\
\text { decentralization, greater } \\
\text { autonomy and community } \\
\text { control }\end{array}$ \\
\hline $\begin{array}{l}1971-1990 \\
\text { (Period of nationalism } \\
\text { in education) }\end{array}$ & $\begin{array}{l}\text { Greater state involvement in education, } \\
\text { standardization and nationalism in education }\end{array}$ & $\begin{array}{l}\text { Extreme centralization in } \\
\text { educational management }\end{array}$ \\
\hline $\begin{array}{l}1990-\text { date } \\
\text { (Period of } \\
\text { democratization of } \\
\text { education) }\end{array}$ & $\begin{array}{l}\text { Expansion of school education, high donor } \\
\text { involvement, greater commitment to universal } \\
\text { primary education, decentralization in state school } \\
\text { management, and uncontrolled growth of private } \\
\text { education }\end{array}$ & $\begin{array}{l}\text { Shift towards } \\
\text { decentralization and } \\
\text { community involvement in } \\
\text { education. }\end{array}$ \\
\hline
\end{tabular}

In the sub-sections that follow, the researcher analyzes the educational developments and policies in those four periods, keeping a central focus on the debates of centralization and decentralization of school education.

\subsection{Opposition to schooling: selective exclusion under the Rana rules}

The Rana rulers, who governed Nepal by an oligarchy for more than a century (1846 - 1950), feared an educated public. Education was seen as a threat to the power of the rulers, who were deeply afraid of "giving 
education to the common people, lest they should be awakened and be conscious of their rights" (Shakya, 1977, p. 19). The Ranas kept education the exclusive prerogative of the ruling elite. However, meager of educational development took place over the century of the Rana regime because of a liberal attitude of some Rana rulers.

The first Rana Prime Minister, Jang Bahadur Rana, being impressed by English education during his visit to Britain in 1952, established a school in the palace in 1953 with the aim of providing English education for Ranas' children. ${ }^{7}$ Jang Bahadur's successor later shifted the school to a public building giving it a new name, the Durbar High School. A brief shift in government education policy came in 1901, when the liberal Prime Minister Dev Shumsher Rana took office and issued an ordinance to open schools throughout the country. Nearly 50 Bhasha Pathashala (elementary Nepali language schools) were opened in the Kathmandu Valley and over 100 outside. He proposed a system of universal public primary education and Nepali as the language of instruction. He also opened the Durbar High School to children who were not members of the Rana clan. Dev Shumsher's policies were so unpopular among the Rana rulers that he was deposed within a few months. His call for reforms did not entirely disappear, however. A few Nepali-language primary schools in the Kathmandu Valley, the Hill Region, and the Tarai remained open, and the practice of admitting a few high-caste children to Durbar High School continued.

Before the World War II, a few new English schools were founded in Patan, Biratnagar, and elsewhere, and a girls' high school was opened in Kathmandu. In the villages, public respect for education was increasing, largely as a result of the influence of returning Gurkha soldiers, many of whom had learned to read and write while serving in the British army. Some retired soldiers began giving rudimentary education to children in their villages. Some members of the high-caste, elite families sent their children to Patna University, Banaras Hindu University, or other universities in India for higher academic or technical training. Later in 1918, Chandra Shumsher Rana, who had the longest tenure among the nine Rana Prime Ministers, established Tri-Chandra College, the first college in Nepal. While addressing the opening ceremony, Chandra Shumsher was quoted as saying "I am not sure whether this day will be a day of happiness or a day in the beginning of the end for the Rana regime. I do not see that the result of opening a college will be good to them. I am compelled to do it because of the time and circumstances" (Sharma, 1990, p. 5).

The establishment of Tri-Chandra College, in fact, was necessary to reduce the growing flow of students to India and to lessen the threat of anti-Rana movement inspired and led by Nepali students outside the country. The successors of Chandra Shumsher opened a few more schools in the country, but the attitude of the Ranas towards pro-elite schooling remained largely the same. Before the fall of the Rana regime, Nepal had 310 primary and middle schools, 11 high schools, two colleges, one normal school, and one special technical school. The average literacy rate was less than 5 percent. Literacy among males was 10 percent and among females less than 1 percent. Only 1 child in 100 attended school (Wood, 1959).

In relation to educational governance, the Rana rulers had strong control over the program, regulation and staffing of education institutions. At the central level, the Department of Education (DOE) was established in 1858, and until the end of the Rana's rules in 1950, the DOE was the only institution to govern all kinds of educational institutions across the country. Only Rana army generals were entitled to become the head of the DOE, the Director of Education, and they ignored the importance of professionalizing the office (Wood, 1965). The responsibilities relating to this assignment were minimal, and functions of this were indifferently performed. The Director used to make occasional visits to the schools and provide administrative and managerial guidance on his own. No clear policy was formulated to run the schools. However, from 1932 onwards, with the establishment of the School Leaving Certificate (SLC) examination board, various functions and responsibilities were added to the Directorate office. Some of these responsibilities are setting standards, supervision of Tri-Chandra college, opening new schools, issuing financial grants to government-operated schools, establishing and financing teacher education (a small beginning was made in 1947), and publishing materials in Nepali. Later,

\footnotetext{
7 The establishment of this school marked the beginning of the modern educational history of Nepal. Being organised in the palace (Durbar) later it is known as Durbar High School. It is now located at the heart of the Kathmandu city.
} 
in 1939, the first education ordinance, the Shiksha Istihar, was passed which legally consolidated the authority of the DOE to control administration and finance of the education institutions in the country. It seemed that whatever dismal quantity of educational development took place during the reign of Ranas, it focused on creating a highly stratified society, and the highly centralized and regulated educational development over the century contributed, in part, to isolating the entire Nepalese populace from a small group of ruling elites.

\subsection{Proliferation of community schooling: Education in the new democracy}

The overthrow of the century-old Rana autocracy in Nepal, the impetus given to education by some ruling elites, and the initiatives of some youths, mainly educated in India, in establishing schools in their own communities combined to offer a favorable atmosphere for the education expansions immediately after 1950. However, there were tremendous challenges to exploit the available opportunities. Hugh B. Wood, a professor of the University of Oregon who worked as an Educational Advisor in Nepal during 1953-1959, summarized the fundamental challenges of the country at that time to meet the growing aspiration of the citizens (Wood, 1965, p. 120).

$>\quad$ Sudden freedom of 8.5 million people in an abyss of illiteracy (98\%)

$>\quad$ A tremendous "thirst for learning"

$>\quad$ No schools, no educational system, no educational traditions

$>\quad$ No experienced educational leaders, no pool of educated or partially educated persons ready for professional training (300 in all the country had college degrees, 1000 had graduated from high school)

$>\quad$ An expressed desire for universal primary education by 1985 , widespread adult literacy by 1970 , comprehensive secondary schools for 10 per cent of youth by 1965, and a national university by 1960

$>\quad$ No substantial economic resources and little foreseeable potential.

There were no easy solution to address those myriad challenges, and above all, the problem of resources, both the human and financial, was immense. The communities, mostly in urban locale and southern Terai, however, did not wait for the government's action, and began to take steps voluntarily to open schools with their own resources and initiatives. With local initiatives, schools were opened rapidly in many parts of the country but often without adequate planning, financing and facilities. Nearly all of them charged tuition fees and catered to the favored socio-economic classes (Wood, 1959). To prevent complete chaos and provide some guidance for educational institutions, several organizational steps were taken during the middle of the 1950s. These included the establishment of the Ministry of Education, strengthening the Educational Directorate, and appointment of seven school inspectors. A Board of Education was appointed, and in 1954-55, a Nepal National Education Planning Commission (NNEPC) mapped out a long-range plan for the orderly development of education in Nepal.

Under the recommendation of NNEPC, the ministry constituted a few policies on school governance and management. There was a problem of enforcing these policies uniformly, however. In practice, the government had little control over the schools; much was left in the hands of the head teachers and the community leaders. To systematize the functioning of the schools, the communities were entrusted to form a management committee comprising parents and school leaders. This was a self-perpetuating body, or used to be appointed by the school staff if the school was privately founded. If the school had been established by local elders, then the founding group may appoint a management committee, or serve in that capacity itself (Wood, 1959). The management committee had authorities to raise money, approve new courses, and discuss and approve school policies. It was also entrusted with responsibilities for decision-making about curriculum, budgeting, and management. 
An important feature of the educational development between 1951 and 1960 was that communities were entrusted with the school business: school founding, teacher selection, course approval, revenue collection and school management. There was a growing realization that school is integral to the community development and the community should take responsibility for education in its area.

The MOE was to provide the broader policy guidance and support:

The Ministry of Education of the central government will be the organizing force, will provide leadership and necessary uniformity, will ensure minimum standards, and direct the training of teachers, but each village must take the major responsibility for education in its area. Each village will have a board of education or education committee to organize and supervise education in general, and will employ a competent administer to administer the schools (NNEPC, 1956, p. 84).

There were three major reasons for decentralizing the responsibility for founding and managing the schools during the 1950s. First, the downfall of the Rana oligarchy unleashed an unprecedented public aspiration for education. This resulted in a spontaneous movement for the foundation and management of schools. Second, the government aimed to run public institutions based on the democratic principle of governance; as a result, communities were entrusted with the responsibility of school foundation, teacher selection, course approval, revenue collection and school management. Third, there was a high degree of mismatch between the people's growing aspiration and the government's available resources for education. Thus, in order to meet the rising cost of schooling, the government had to rely on the community resources and budget.

\subsection{Centralization and nationalism in the Panchayat era}

Nearly ten years after imposing a ban on the political parties, the Panchayat government introduced a very ambitious reform in education in 1971 - the Nepal Education System Plan (NESP) to 'suit' the changed political context. The NESP had two political goals - to strengthen the 'national integration' with a focus on unity around a common language (Nepali) and a common religion and culture (Hinduism) (Shah, 1993) and to instill a faith in the Crown through politics, media and curriculum (Onta, 1996). Towards these goals, the national system of education employed various programs and strategies including instruction in Nepali, a uniform curriculum, allegiance in the curriculum to the Crown and to the Panchayat system, a national examination system, and strong central administration (NESP, 1971).

All these were pursued under a highly centralized and regulated system, which eventually downplayed the role of communities in school development as well as cut off the schools' long-established relations with their communities. As a result, a common feeling tended to grow among the commoners that education was a sole responsibility of the state and communities had no role to play in the schools (Reed, 1979; Panta, 2001).

The centralized education in the Panchayat period pursued its goal through the educational program, and curriculum was used as a key instrument for transmitting the ideals and goals of the nationalized education. The curriculum was broadly guided by the national goal of education:

To strengthen devotion to crown, country, national unity and the Panchayat system, to develop uniform traditions in education by bringing together various patterns under a single national policy, to limit the tradition of regional languages, to encourage financial and social mobility, and to fulfill manpower requirements essential for national development (NESP, 1971, p. 1).

Comparing the NNEPC policy on school curriculum with that of the NESP, one can see a major difference in curricular focus. The NNEPC policy stressed "the context of the curriculum must be adapted to the culture and needs of the people" (NNEPC, 1956, p.8), whereas the NESP curriculum placed little emphasis on the local characteristics, needs and variations. In contrast, the NESP aimed to promote 'Nepaliness' underpinned by the 
widely promoted vision of the Panchyat 'ek bhasha, ek bhesh, ek desh' (one language, one dress, one nation) (Caddell, 2007).

In line with this political agenda, the NESP sought to use school curricula to "preserve, develop and propagate the national language and literature, culture and arts" (NESP, 1971, p. 8, emphasis added). Nepali was reconfirmed as the medium of instruction in the primary and secondary schools and textbooks were recognized as the "most important item of educational material" as it was only such thing "used throughout the country" (NESP, 1971; p. 32). The contents of the textbooks, mainly of the three core subjects - Nepali, Social Study and Panchayat $^{8}$ - used as a vehicle for promoting the sense of anekatama ekata (unity within diversity) and strengthening faith in the Panchyat system and the Crown by portraying them as icons of 'unity' and 'development'. Therefore, curricula and textbooks - the chief material resources - started to produce centrally through rigorous scrutiny by officials at the newly established centre in Kathmandu - the Curriculum, Textbook and Inspection Development Center and through a sanction of the Education Ministry.

The author was schooled during the latter years of the Panchayat period, thus has a good recollection that the front cover of each textbook was adorned with a symbolic icon of 'national unity' and the back cover with the Kakchhagat Geet, a song dedicated to the Nation and the Crown. The contents were carefully crafted with a heavy stress on 'sameness' rather than diversity and the lives of the 'national' heroes and the contribution of the Saha Kings to the building of the nation. For example, at the time when the author was a seventh-grade student, the Social Study textbook was filled largely with the histories and contribution of the Shah Kings, beginning from the first King Prithvi Narayan Saha to the King Birendra Saha. Similarly, a poem Nalapani, perhaps known by every student schooled in the Panchayat Era, portrayed proficiently how Balabhadra (a commander of Nepali Army) and his soldiers fought against the well-armed British troops in a victorious day during the Anglo-Nepal War (1814-16). The poem says that the Khukuries ${ }^{9}$ glittered on the top of the hill-fortress as they sliced the enemy like radishes, and Nepalese, including women and children, fought bravely at Nalapani at a great loss to the enemy.

Indeed, the Panchayat picked up and portrayed such a selective episode of history to reinvigorate a new form of state-produced 'nationalism'. Onta points out that the Panchayat tried to write the Nepali nation history by creating a sensibility of a shared history, what he called this Rastriya Itihas (National History) and appropriating its bir (brave) and virile characterization as the central theme of Nepali nation culture (Onta, 1996). However, it closed its eyes to the contribution to the nation building of the ethnic minorities, cultural heroes and tribal leaders, who represent more than $50 \%$ of the country's population. While devising a plan for national integration, ethnic and tribal characters were deliberately made invisible in the state-produced history with the so-called reason that they "did not fit within the straitjacket of Nepaliness" (Brown, 1996, p. 75). With its goal to "integrate multilingual traditions into one all-embracing nation" (NESP, 1971, p.12), Nepali was made the official language not only in schools as a medium of instruction but also in the judiciary and the government offices.

While half of the population speaks a mother tongue other than Nepali, linguistic policy to boost 'Nepaliness' by making Nepali the official language proved to be favorable for the elite Brahmin caste but injurious to the educational and political mainstreaming of the ethnic population (Lawoti, 2005). Thus, the Panchayat 'nationalism' largely failed to embrace and accommodate the country's linguistic, ethnic and cultural plurality. As the political system had banned the political parties and nobody was allowed to raise voice against the Panchayat system, the nationalistic feeling of 'commonness' or 'Nepaliness', was forcefully propagated during the three decades (1960-1990) of the Panchayat era.

The Panchyat polity, in fact, was built on very strategic and ambitious projects like the NESP. From the

\footnotetext{
${ }^{8}$ A separate subject called 'Panchayat' was introduced at the lower secondary level (grade 6,7 and 8) with the aim of instilling faith in the political philosophy of Panchayat system and informing students about their rights and duties as citizens of the country.

Khukuri is a curved Nepali knife used as a tool as well as a weapon.
} 
outset, it prepared its political defenders from the centre to the village. While the NESP in the beginning did not see the need for any school level committee, later in 1974 School Assistance Committees were formed in each school with its trusted defenders in the village. These committees, however, were not provided with management authority. They were made ancillary bodies to the DEOs for ensuring that the schools were adhering to the government's policy and direction. More than this, these committees were encouraged to ensure that no anti-Panchayat activities were taking place in the school community. No authority was devolved to take local decisions on major educational affairs such as curriculum, teaching, budgeting and teacher recruitment. Any such committees would be dissolved as and when they failed to be accountable to the government for the given tasks, but no horizontal and downward accountability were sought.

In relation to educational governance, the NESP aimed to tighten control over school policies and decision-making. Towards this aim, the NESP brought the Tribhuvan University, the MOE and other Ministries involved in educational endeavors under a high-level national education committee led by the King. So their independent functions were discouraged, and a new practice of educational sanction began. The Regional Education Directorates functioning in the five developmental regions and the DEOs in 75 districts were made accountable to the MOE, with responsibilities for ensuring that the central policies had been effectively implemented in their jurisdictions. While the NESP at its outset did not propose any school-based committee, later in 1974 the MOE introduced a policy to 'oversee' the schools by a school-based committee comprising local leaders handpicked by the government. These committees were made ancillary bodies to the DEO with the responsibility for establishing a direct link between the government units (such as the DEO) and the schools. These committees were also used as a pro-Panchayat unit in the village and often encouraged to report to the district officials if any anti-Panchayat activities were taking place in the school communities.

The NESP's political goals of 'nationalism' and 'centralization' demonstrate that education policy in a highly regulated system may contribute to the particular ideology and governance system. While one can hardly deny the NESP's contribution to consolidating the institutional, infrastructural and professional foundation of school education across the country, it has been criticized for ignoring the role of community in school development, 'software' policy for instilling a feeling of 'one county one culture' nationalism and overemphasis on 'national history'. The overall implications of centralized education during the Panchayat period are the increasing alienation of communities from the schools, the perpetuation of socio-cultural inequality, and "the political marginalization of the majority of the population whose poverty was ...both created and maintained by their economic, political and social subservience to the national elite" (Brown, 1996, p. 51).

\subsection{Reversing the locus of power: Education after the restoration of democracy}

The political change in 1990, which restored the multiparty democracy in the country, required a substantial change in Nepali educational policies and programs. Interestingly, the democratic reinstatement in the country and the beginning of the global campaign for the EFA movement coincided in 1990, which immediately necessitated addressing two major concerns. First, the restored democracy had to remedy the political ills of the Panchayat system, and secondly, a comprehensive plan was to be designed in response to the EFA declaration.

To address the first concern, the government constituted a high level commission in 1991 - the National Education Commission (NEC). The NEC shifted the policy focus from the Panchayat-based "pro-palace patriotism" and "nationalism" to "human resource development", exploring the "possibilities of personal development" and promoting "human values". Individuals were to "embrace diversity" and to "live in harmony" in the "modern age" and develop in ways that would not "jeopardize their identity" (NEC, 1992, p. 13). In addition, the NEC recommended limiting the role of the MOE to "the formulation of policies and plans" and the "follow-up and assessment programs" and sought a greater role of the regional, district and school sectors to implement these policies at the local level.

Concurrently, the government launched a 10-year Basic and Primary Education Program (BPEP) in response 
to the universal declaration of the EFA, keeping a central focus on three overarching outcomes: improvement in access, quality and management (MOE, 1991). The project was supported financially by the major donor agencies including the World Bank, UNDP (United Nations Development Program), JICA (Japan International Cooperation Agency) and DANIDA (Danish International Development Agency). The first phase of the project BPEP I (1992-97) - brought about a number of changes in school education, and with regard to the school management, this project took steps towards decentralizing educational provision focusing on three goals: empowering school heads with additional authority, providing the SMCs with greater autonomy and elevating the role of the VDCs and Municipalities in school management and development (MOE, 1991).

The second Master Plan - BPEP II (1997-2003) - reemphasized the need for enhancing 'efficiency' measured in terms of the retention rate and 'quality' through tangible gains in children's learning achievement. This need was clearly highlighted by the major donor agencies including the World Bank for approval of its loan assistance (MOE, 1999). The aid agencies emphasized the need for empowering local communities in order to avoid persistent problems of the weak functioning and poor management of schools (World Bank, 1999). The BPEP Master Plan II recognized the need to provide the SMCs with additional power to make the school plan, monitor school operations, recruit temporary teachers, and control financial decisions. In addition, the first part of the BPEP II mid-review that took place in 2001 further recommended a move towards community ownership of state schools, providing block grants to schools and improving the capacity of the school and community to manage its school (MOE, 2002).

In the political arena, the democratically elected government, with a new spirit to elevate the role of people's representatives in decision-making, was opting for the devolution of power from central to local government following the local election in 1993. In 1998, the government passed the Local Self Governance Act to empower the local governance bodies such as the VDCs and Municipalities. This Act elevated the role of the VDCs and Municipalities in formulating and executing the Village Education Plan and provided a legal tool to bring into effect the BPEP's plan to establish the Village Education Committee (VEC) in each village unit. All these efforts were brought to fruition when the government came up with a comprehensive policy with the provision of transferring the management of state schools to local communities (SMCs, VDCs/ Municipalities) by amending the Education Act in 2001. At its heart, the Act established the SMC's primacy in school decisions, bringing back the legal power of local community in school management. For the first time, the Act formalized the election of the SMC, in which the chairperson and other representatives of the community were to be elected by the votes of the parents or guardians whose children were enrolled in the school. The Act provided the SMCs with authority to operate monitor and manage the school. Above all, the SMCs were allowed to take over the school management from the government, meeting some basic prerequisites.

The post-1990 development in education in Nepal can be viewed from two perspectives. Firstly, with the fall of the Panchayat regime and the restoration of democracy, the Nepali nation was trying to redress the fallout of the Panchayat-based centralization and nationalism by endowing the country with a 'multiethnic, multilingual, sovereign and democratic' status in the constitution and by redefining 'the nation' as:

Having common aspirations and united by a bond of allegiance to national independence and integrity of Nepal, the Nepali people irrespective of religion, race, caste or tribe, collectively constitute the nation (Article, 2, The Constitution of Nepal, 1990) (HMG, 1990).

The words of the similar Article in the Panchayat Constitution were sharply different and had assumed the people "united by the common bond of allegiance to the Crown" (Article 2, The Constitution of Nepal, 1962) (HMG, 1962). Similarly, an articulation of the 1990 constitution - "the sovereignty of Nepal is vested on the Nepali people" (Article 3) - had a powerful implication for shifting the locus of power from the Palace to the people. In fact, the incorporation of 'multiethnic', 'multilingual' and 'democratic' into the basic definition of the state was emblematic of discontent with the assimilationist and hegemonic ideologies of the Panchayat political system (Hutt, 1993). The constitutional provisions of the 1990 Constitution such as "each community residing 
within the Kingdom of Nepal shall have the right to preserve and promote its language, script and culture" (Article 18/1) and "each community shall have the right to operate schools up to the primary level in its own mother tongue for imparting education to its children" (Article 18/2) also epitomized an antidote to the mono-cultural policy of the past.

All those constitutional provisions indicate that the Nepali nation was seeking a greater reform in the state policy including education, focusing on the establishment of democratic institutions and localization of power (Ellingson, 1991). This is truly reflected in the subsequent NEC report which recommended various strategies to "allow everybody to develop his [sic] language, literature, script, art, culture in healthy, happy harmony with all other religions, ethnic groups, communities and languages" (NEC, 1992, p. 6). Therefore, the post-1990 reform underpinning decentralization can be viewed from the perspective of the need for redressing the unitary politics of the Panchayat system and the country's renewed move towards, and aspiration for, 'democracy' and 'modernity'.

Secondly, the post-1990 reform in education can be viewed from the globalization perspective. In particular, the impact of global forces on policy reform rose to prominence following Nepal's commitment to the EFA World Declaration. By setting the global agendas, standards and commitments, such universal declarations put developing countries like Nepal under pressure to rely on international policy assistance and guidelines. The country's broader education reform such as the BPEP I and II in the 1990s, which laid the foundation for school decentralization reform, for example, were built on such guidelines and consensus agreed on the international platforms. Such reforms have been supported, if not shaped explicitly, by international aid donors (Carney and Bista, 2009). The current trends suggest that Nepal's ongoing "policy directions have continued to be determined largely by donor funding trends" (Robinson-Pant, 2010, p. 143).

\section{Conclusion}

The current school decentralization policy has been shaped by the confluence of three salient forces historic, democratic and global. Historically, there were three major prodemocracy developments which aimed to empower local people and communities - the anti-Rana movement and establishment of democracy in 1950, democratic developments between 1951 and 1961, and the fall of the Panchayat polity and restoration of democracy in 1990. The extreme centralization of political power and political monopoly are the characteristic features of the Rana and the Panchayat governments. The centralization of power during the Rana and the Panchayat period left indelible imprints of the political elitism, isolation and marginalization and also stamped out the culture, languages and histories of the indigenous communities. The lack of the community contribution to school development and the lack of equitable access to schooling in those periods were, in part, attributed to the escalation of practices to de-cement the link between the schools and their communities. On the other hand, the relaxation of central control and democratic developments over the decade following the fall of the Rana regime left a rewarding experience of a high degree of community involvement in school foundation and development. If the government had been able to systematize the community contribution to schools, this period could be exemplified as a marvelous age of community schooling.

The educational policies and reforms in recent times have been influenced much by global forces. Coupled with the international policy mandates and declarations, global forces appear to have had a good deal of effect on the domestic policy in Nepal since the early 1990s. In particular, the global campaign of EFA movement and the 'support' of the World Bank, UNESCO and other international organizations, particularly after 1990, played a catalytic role in introducing the educational policies and reforms underpinning decentralization. Notably, aid donors including the World Bank always have certain loan conditionality that might impinge upon domestic policy agendas and processes. The ongoing School Sector Reform Program (2009 - 2015) funded by the World Bank and other aid donors, for example, is built on the official 'negotiations' between the Government of Nepal and its donor partners. The SSRP Financial Agreement that was signed on 27 November 2009 between the Government of Nepal and the International Development Association demonstrates how the agendas of school 
reform are negotiated, prioritized and financed (see World Bank, 2009).

As Nepal is preparing for a large-scale structural transformation by drafting a federal constitution and given that many ethnic and political groups are lobbying for power sharing, the shape of school decentralization in future seems to be affected by the outcomes of this process as well. The major concern at the political level now is how to distribute power at various levels of governance and among various groups of people and how to devise context-specific reforms in public education. It should also be noted that policy often fails to function because of its inability to diagnose the grounded reality in the local context and the inability to put the policy goals into actionable steps $(\mathrm{Ng}, 2008)$. Indeed, policy itself is always a contested field as it is "affected by the dynamic interaction between the central government and other system levels, where different values and survival issues take central stage" $(\mathrm{Ng}, 2008$, p. 597). Thus, rather than relying solely on the 'global' policy and donor-driven agenda, it is essential to consider the school decentralization policy based on the needs, strategies and priorities of the diverse communities in the country.

The analysis, overall, reveals that the educational policy-making in Nepal has been a top-down process whereby politicians and international aid groups transfer their own values, interests and preferences into public policies. There has been little evidence that such policies came out of local needs and clamor. This study suggests for a bottom-up process in the making of public policy. In top-down policy-making, as Dye (2001) argues, behind-the-scene activities of funding agencies, policy planning organizations, think tanks, political campaign contributors, special-interest groups, lobbyists, influence-peddlers and national news media are more powerful than the people's concerns and voices. A better alternative, therefore, might be to take concerted steps to revisit the policy process on the ground where implementation takes place and from the viewpoint of those who implement policies at the point of contact with the policy's target population, what Lipskey (2010) calls the street-level bureaucrats. Such a bottom-up approach to policy-making process, what Elmore (1980) describes as 'backward mapping', begins by understanding goals, motivations and capabilities of these lowest level implementers and follows the policy design upward to the highest level initiators of policy.

\section{References:}

Baral, L. R. (1980). Nepal in 1979: Political system in crisis. Asian Survey, 20(2), 197 - 205. http://dx.doi.org/10.2307/2644023

Brown, L. (1996). The challenge to democracy in Nepal: A political history. Routledge: London. http://dx.doi.org/10.4324/9780203419649

Burghart, R. (1996). The conditions of listening: Essays on religion, history and politics in South Asia. Delhi: Oxford University Press.

Caddell, M. (2007). Education and change: A historical perspective on schooling, development and the Nepali Nation-state. In K. Kumar \& O. Joachim (Eds.), Education and social change in South Asia (pp. 251 284). Buckingham: Open University Press.

Carney, S., \& Bista, M. B. (2009). Community schooling in Nepal: A genealogy of education reform since 1990. Comparative Education Review, 53(2), 189 - 211. http://dx.doi.org/10.1086/597394

Carney, S., Bista, M. B., \& Agergaard, J. (2007). Empowering' the 'local' through education? Empowering community-managed schooling in Nepal. Oxford Review of Education, 33(5), 611 - 628. http://dx.doi.org/10.1080/03054980701476253

Devkota, G. B. (2036 B.S.). Political mirror of Nepal [In Nepali]. Kathmandu: Dhruba Bahadur Devkota.

Dye, T. R. (2001). Top down policymaking. New York, NY: Chatham House.

Ellingson, T. (1991). The Nepal Constitution of 1990: Preliminary considerations. Himalayan Research Bulletin, $X I(1 / 3), 1-17$.

Elmore, R. (1980). Backward mapping: Implementation research and policy decisions. Political Science Quarterly, 94(4), 601 - 616. http://dx.doi.org/10.2307/2149628

Fiske, E. B. (1996). Decentralization of education: Politics and consensus. Washington, DC: World Bank.

Gaige, F. H. (1968). Nepal: Compromise and liberalization. Asian Survey, 9(2), 94 - 98. 
http://dx.doi.org/10.2307/2642307

Gellner, D. N. (2007). Democracy in Nepal: Four models. Seminar, 576, 50 - 56.

Gurung, H. (1982). The sociology of election of Nepal 1959 to 1989. Asian Survey, 22(3), $304-314$. http://dx.doi.org/10.1525/as.1982.22.3.01p03633

HMG. (1962). The constitution of Nepal 1962 AD. Kathmandu: Kanun Kitab Mahal.

HMG. (1990). The constitution of Nepal 1990 AD. Kathmandu: Nepal Law Commission.

HMG. (1999). Local self-government Act 1999. Kathmandu: Kanun Kitab Mahal.

Hutt, M. (1993). Drafting the 1990 constitution. In M. Hutt (Ed.), Nepal in the nineties: Versions of the past, visions of the future (pp. 14 - 27). Delhi: Oxford University Press.

Koirala, N. (1991). Nepal in 1990: End of an era. Asian Survey, XXXI(2), 134 - 139. http://dx.doi.org/10.2307/2644923

Lawoti, M. (2005). Towards a democratic Nepal: Inclusive political institutions for a multicultural society. New Delhi: Sage.

Lipsky, M. (2010). Street-level bureaucracy (30th anniversary expanded Ed.). New York, NY: Russell Sage Foundation.

McGinn, N. F., \& Welsh, T. W. (1999). Decentralization of education: why, when, what and how? Paris: UNESCO/IIEP.

MOE. (1991). Basic and primary education program master plan. Kathmandu: Author.

MOE. (1999). Basic and primary education program master plan. Kathmandu: Author.

MOE. (2002). Nepal basic and primary education program II: Joint government-donor mid-term review. Kathmandu: Author.

NEC. (1992). Report of the national education commission. Kathmandu: MOE.

NESP. (1971). Report of the national education systematic plan. Kathmandu: Ministry of Education.

$\mathrm{Ng}$, P. T. (2008) Education policy rhetoric and reality gap: A reflection. International Journal of Educational Management, 22(6), 595 - 602. http://dx.doi.org/10.1108/09513540810895471

NNEPC. (1956). Education in Nepal: Report of the National Education Planning Commission. Kathmandu: Bureau of Publication.

Onta, P. (1996). Ambivalence denied: The making of Rastriya Itihas in Panchayat era textbook. Contributions to Nepalese Studies, 23(1), 213 - 54.

Onta, P. (2000, November 18). Nepal education: finding a ray of hope, Economic and Political Weekly, 4093 4096.

Pant, Y. R. (2001). Community support to education: research study report. Kathmandu: Danish Support to Education.

Reed, H. B. (1979). Nepalese education related to national unity, economic development and social justice. Comparative Education, 15(1), 43 - 61. http://dx.doi.org/10.1080/0305006790150106

Robinson-Pant, A. (2010). Changing discourses: Literacy and development in Nepal. International Journal of Educational Development, 32(2), 136 - 144. http://dx.doi.org/10.1016/j.ijedudev.2009.04.002

Shah, S. (1993). Throes of fledgling nation. Himal, 6(2), 7 - 10.

Shakya, T. M. (1977). National Education System Plan: An analysis. Kathmandu: Ratna Book.

Sharma, G. P. (1990). The impact of education during the Rana period in Nepal. Himalayan Research Bulletin, $X(2 / 3), 3-7$.

Wood, H. B. (1959). Development of education in Nepal. Educational Leadership, 16(7), 429 - 433.

Wood, H. B. (1965). The development of education in Nepal. Washington, DC: Office of Education.

World Bank. (1999). Education sector work. Kathmandu: Author.

World Bank. (2003). Project appraisal document for community school support project. Kathmandu: Author.

World Bank. (2009). Financial agreement (School Sector Reform Project) between Nepal and International Development Association. Retrieved January 12, 2010, from http://www-wds.worldbank.org/external/default/WDSContentServer/WDSP/SAR/2010/04/19/EE01097 B14D644AD8525769B005BE31E/2_0/Rendered/PDF/4652FA.pdf 